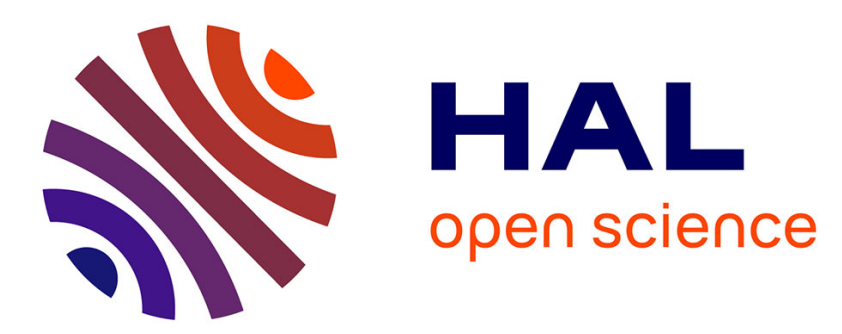

\title{
Pareto, Mill and the cognitive explanation of collective beliefs. Unnoticed "middle-range theories" in the Trattato
}

Alban Bouvier

\section{- To cite this version:}

Alban Bouvier. Pareto, Mill and the cognitive explanation of collective beliefs. Unnoticed "middlerange theories" in the Trattato. Joseph V. Femia and Alasdair J. Marshall. Beyond Disciplinary Boundaries: Essays on Pareto, Ashgate, 2011. ijn_01081450

\section{HAL Id: ijn_01081450 \\ https://hal.science/ijn_01081450}

Submitted on 7 Nov 2014

HAL is a multi-disciplinary open access archive for the deposit and dissemination of scientific research documents, whether they are published or not. The documents may come from teaching and research institutions in France or abroad, or from public or private research centers.
L'archive ouverte pluridisciplinaire HAL, est destinée au dépôt et à la diffusion de documents scientifiques de niveau recherche, publiés ou non, émanant des établissements d'enseignement et de recherche français ou étrangers, des laboratoires publics ou privés. 


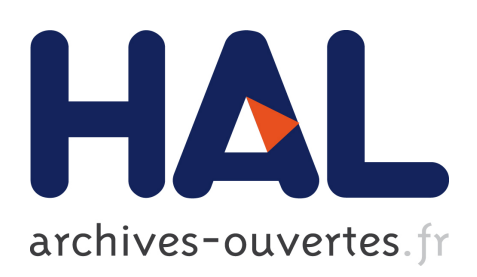

\section{Pareto, Mill and the cognitive explanation of collective beliefs. Unnoticed "middle-range theories" in the Trattato.}

Alban Bouvier

\section{- To cite this version:}

Alban Bouvier. Pareto, Mill and the cognitive explanation of collective beliefs. Unnoticed "middle-range theories" in the Trattato.. Beyond Disciplinary Boundaries: Essays on Pareto, by Joseph V. Femia and Alasdair J. Marshall (eds), 2011, Ashgate, Aldershot, 2011. $<$ ijn_01081450>

\section{HAL Id: ijn_01081450 \\ http://jeannicod.ccsd.cnrs.fr/ijn_01081450}

Submitted on 7 Nov 2014

HAL is a multi-disciplinary open access archive for the deposit and dissemination of scientific research documents, whether they are published or not. The documents may come from teaching and research institutions in France or abroad, or from public or private research centers.
L'archive ouverte pluridisciplinaire HAL, est destinée au dépôt et à la diffusion de documents scientifiques de niveau recherche, publiés ou non, émanant des établissements d'enseignement et de recherche français ou étrangers, des laboratoires publics ou privés. 
in Joseph V. Femia and Alasdair J. Marshall (eds), 2011, Beyond Disciplinary

Boundaries: Essays on Pareto, Ashgate, Aldershot>

Pareto, Mill and the cognitive explanation of collective beliefs. Unnoticed "middle-range theories" in the Trattato.

\section{by Alban Bouvier.}

\section{O/INTRODUCTION}

Sociology is a science in which there is neither an overarching theory to which all scientists are ready to commit (as is the case for biology), nor even a general mainstream to which most scholars belong (as is the case for economics). I am speaking here of sociology as a specific field in social science, whose boundaries with other fields, in particular ethnology and history, are indeterminate and quite controversial. In a context where no paradigm is prominent, it seems more relevant than in other sciences to return to the discipline's founding works. One can expect that important heuristic paths outlined by the pioneers were not explored in as much depth as they could have been early in the discipline's history. The investigation of only certain paths might have been favoured initially, which forever buried potentially productive modes of inquiry - perhaps for incidental reasons. Thus in sociology, since Talcott Parsons (1937), who seemed to have been aware of the risk of laying aside important heuristic ideas, a very common way of practicing theory has come to be through commenting on founders' works. Of course, this indirect way is not the only way to proceed in the development of social sciences. And Habermas (1984-7) was rightly reproached for restricting, unlike Parsons (1951), his interests in sociological theory to commentaries on founders' works. But no way should be neglected, however indirect and partial it may be. And Habermas was reproached above all not for having commented at length on Marx, Durkheim or G.-H. Mead, but for having failed to extract empirically testable analytical models. ${ }^{1}$

Unlike Habermas, a few scholars have recently undertaken such work and have produced fruitful results, even regarding the works of the most renowned founders of social science whose views had been underestimated or neglected, either in theoretical sociology or in the philosophy of social phenomena. Thus certain historical commentaries have given birth to a specific analytical modelling of social phenomena. Jon Elster is one of these scholars. He has published very innovative rereadings of Marx (Elster, 1995) and Tocqueville (Elster, 1993) useful for political scientists. Raymond Boudon (1994) did similar work on various classical authors such as Weber and

\footnotetext{
${ }^{1}$ I wish to thank the participants of a workshop held in Manchester devoted to a discussion of the first drafts of this book (11-12 February 2010), as well as my Italian colleagues and Ph.D students for their very relevant comments on two lectures on this issue given in Perugia and organized by Caterina Federici (16-17 March 2010). I am especially indebted to a Columbia Ph.D. student, Amelia Spooner, for her meticulous written comments on the penultimate version of this chapter.
} 
Tocqueville, as well as Simmel. In particular, Boudon showed how productive some of Simmel's ideas are for contemporary sociology of knowledge and cognitive sociology. Finally, in a very different style distant from exegetic comments - but nonetheless analytical, as Elster's and Boudon's work is - Margaret Gilbert's $(1989,1994)$ rereading of classic authors such as Durkheim and Simmel on the elementary nature of groups is, according to many theoreticians, another exemplary way of reviving ideas that may have not been thoroughly investigated analytically in earlier scholarship.

The prominent fathers of sociology who have not been as thoroughly reevaluated as Marx, Weber, Tocqueville or Durkheim have been, now deserve our special attention. Pareto is probably one of these founders whose sociological work still remains relatively little commented on. Turner, Beeghley and Powers (1981), Powers (1987), Boudon (1981,1994, 1999), Busino (1999), Bouvier (1992, 1995, 1999b, c, 2000), Femia (2006, 2009) and Marshall (2007), searching much more systematically than Talcott Parsons for analytical explanatory models in Pareto's work have taken such an approach. The aim of this paper is not to suggest that careful comments on Vilfredo Pareto's sociology could at last provide us with the "missing" overarching theory in sociology more than commentaries on Marx, Durkheim or any other classic author could. I argue that such a theory, if it is to exist, should consist of a number of micro-models, such as those Elster, Boudon and Gilbert, carefully constructed. These micro-models will look like what Merton (1957) called "middle-range theories", whose concern is to help account for psychological mechanisms and social microinteractions from which larger social phenomena emerge (Hedström and Swedberg, 1998, Hedström and Bearman, 2009). What I claim is that Pareto has provided us with numerous micro-models in sociology, of which some are original, but to some extent still need to be evaluated. Besides, these "models" are generally far too vague in Pareto's Trattato di Sociologia Generale to be considered as conceptual models strictly speaking; they are rather just "schemas," all almost very partially drawn. My specific goal in this paper is to try to transform these schemas into much clearer and more explicit conceptual models in order to better evaluate their empirical relevance, which implies making more conceptual distinctions than is common in comments on Pareto's sociology. To better evaluate the originality of Pareto's modeling, I will compare it to other social theorists'.

Even if it is probably not the real core of Pareto's sociology (Turner et al.,1981, and Powers, 1987), the most original part of Pareto's Trattato deals with the very contemporary issues of the rationality of beliefs and the rationality of actions (Valade, 1990). These two latter issues are connected, given that many actions can be considered as rational or irrational depending on the rationality of the beliefs upon which they are based. I will concentrate in this paper on the sole issue of the rationality of beliefs, more precisely, collective beliefs. I do not contend that Pareto made a thorough examination of these general issues. Indeed, in the final part of this paper I will bring our attention to certain important limitations of Pareto's general account of collective beliefs. I also do not maintain that his analyses of singular examples were always profound, because clearly often they were 
not, but that he gave probably the largest account that has ever been given of the various roles that justification of beliefs and actions ("argumentation") can take within a sociological framework. Chaïm Perelman and Lucie Olbrecht-Tyteca (1969), along with contemporary argumentation theoreticians such as Toulmin (1958), Hamblin (1970), may have gone further in the investigation of certain micromechanisms of argumentation. But neither scholar spoke in general of the issues of argumentation procedures within the framework of social science as broadly as Pareto did.

I will proceed step by step, discussing several of the most widely accepted views of Pareto's theory of collective beliefs, arguing that each one is partial and too narrow. In each case, I will introduce new distinctions, which will result in a much broader view of Pareto's conception of beliefs. I will try to avoid Pareto's very idiosyncratic vocabulary as much as possible because, according to Pareto himself, this may be deeply misleading (Pareto, 1935, $\$ 119,868)^{2}$. Furthermore, the meaning of Pareto's specific vocabulary varies largely in the Trattato depending on the specific context. On several occasions, I will prefer John Stuart Mill's wordings, generally clearer than Pareto's. At the end of this paper, I will even use one of Mill's specific psychological micro-models, because it turns out to be more refined and empirically more relevant than Pareto's models. By referring to Mill, who gave both a psychological and logical account of logical errors, I will remain very close to Pareto's programme. As Pareto himself wrote, after speaking of Mill, "It is the province of logic to tell why a reasoning is false. It is the business of sociology to explain its wide acceptance" (\$1411). Pareto thought of his sociology as the complement of Mill's logic, ( $\$ 1410-1412)$ but he seems to have underestimated the conceptual accuracy and the empirical relevance of psychological models involved in the System of Logic. ${ }^{3}$

The careful investigation of Pareto's micro-models should lead us to re-read Pareto's Trattato di Sociologia Generale in the continuity of Mill's System of Logic and to emphasize the cognitive aspects of Pareto's sociology (Bouvier, 1992) counter to the usual ultra-emotivist interpretations (Aron, 1965). But it should also lead us also to re-evaluate the Machiavellian aspect of his thought, upon which many scholars have insisted for some time (Burnham, 1943, Fiorot, 1969, Femia 2006, Marshall, 2007), in favor of a more complex, less dissembling, and more communicative view of political, moral and religious discourses. The first two parts of this chapter will be devoted to the latter concerns and the remaining sections to the cognitive dimension. The issues, though, are related, in particular the role of emotions in beliefs and in actions.

\section{A CAUSALIST, IRRATIONALIST AND EMOTIVIST SOCIOLOGY OF BELIEFS?}

\footnotetext{
${ }^{2}$ All references to Pareto are to Pareto (1935). I will not specify it any more.

${ }^{3}$ On the relationships between logic and psychology in Mill, see eg. Skorupski (1998).
} 
One does not usually distinguish between different micro-theories or models (or middle-range theories) in Pareto's work, but rather interprets Pareto's sociological theory as one general theory. There are disagreements about the central meaning of this theory, but according to many scholars, Pareto's sociology explains that many actions - namely, those that are not technical actions based on scientific reasons or pragmatic actions which find their grounding in sound empirical information - are based on instinctive motivations alone. According to this interpretation, Pareto would claim that the beliefs or alleged beliefs that often accompany human behaviors and are supposed to justify them turn out to have no causal role at all in triggering these behaviors. Their sole real causes are instincts. It is why one could call such a theory a causalist theory, in opposition to a rationalist theory, which would claim that the reasons people give as explanations of their beliefs and/or actions are - or, at least may be - their true "causes." At first sight, such a rationalist theory could be called "causalist" as well, since it envisions reasons as "causes." But, in this latter case, "cause" is not used in its proper sense: what triggers behaviors (or actions as involving body movements) is necessarily composed of neurophysiological processes - and those are easier to figure out when one thinks of instincts than when one thinks of reasons. Besides, certain philosophers tend to support a dualist view of the mind, so although reasons motivate actions, these reasons cannot be called "causes" of actions in any sense (even in a weak sense): it would be a category mistake. This kind of dualist view was supported initially by Dilthey at the end of the $19^{\text {th }}$ century, but it was reformulated in the mid- $20^{\text {th }}$ century by Wittgenstein in a more subtle - and now common - way (Winch, 1958).

Without a doubt, one can find a causalist-"instinctualist" theory in certain passages of the Trattato. One could even argue that, in some contexts, Pareto seems to suggest that absolutely no belief allegedly supporting actions has any specific role in triggering behaviors or any mental mechanism: beliefs are merely by-products of the instinctive tendency to rationalize, namely to use reason without any specific reason (what Pareto calls the "instinct of combination" or the $1^{\text {st }}$ class of “residues”, §972-5). Beliefs, then, are nothing more than "epiphenomena." Such an extremist theory is clearly anti-functionalist in both a biological sense (see Malinowski's anthropology, for instance) and a sociological sense (as in Radcliffe-Brown's and Parsons's work)(Homans, 1941, 1950). For Pareto, rationalization helps frequently to fulfill neither individual needs nor social needs.

One must notice that such an anti-functionalist account of certain beliefs has been rediscovered by authors such as Steven Pinker (1997) and Pascal Boyer (1994), especially in regard to religious beliefs in general and theology in particular. In such a view, religious beliefs are completely useless by-products of Darwinian evolution. More generally, such a theory resembles eliminativist views, which maintain that neither the notion of belief nor the notion of desire belong to the world of science (Churchland, 1984): rather they are merely commonsense explanations of behaviors, which are to be eliminated and replaced by purely neurophysiological explanations. Anti-functionalism and eliminativism are variations, currently much debated, within the framework of causalist theories. In 
Pareto's time, this rough outline of a theory was original. It has anticipated more contemporary conceptions.

Pareto's sociological theory is sometimes called "irrationalist" to signal its extremist stance (Carroll, 1973, Boudon, 1986), in which reason does not play any role ("strong irrationalism"). That being said, it has been called "irrationalist" as well in a weaker sense ("weak irrationalism"). One could claim that conscious reason - which is necessary to plan actions carefully - often does not illuminate the preparations of actions, so that these actions may often lead to effects contrary to the goals (often self-interest) of those who have acted. Human actors are quite often "irrational" in this sense. Rational action, understood as conscious action based on the best available information and the attempt to reason as logically as possible - what Max Weber called Wertrationalität - is at least subjectively rational (actors expect their actions to achieve certain effects), even if it is not necessary objectively rational (bad information or effectively wrong reasoning results in effects other than those the actor has desired $)(\$ 160,541,855,960)$. An action that is simultaneously subjective and objectively rational is rather rare: actors are often objectively irrational even if they are subjectively rational. The Trattato provides us with arguments for this much more moderate and more subtle theory than strong irrationalism. According to Pareto, the tendency to rationalize is sometimes actually quite valuable, for example, when it leads to actions based on well-informed arguments. Such arguments help humans avoid the bad consequences of the too-limited rationality of purely instinctive behaviors. It is what Pareto oddly calls "logical" actions, as opposed to "non-logical" actions (Pareto, 1935, Chapter II and Chapter III).

Scholars have often suggested that Pareto's theory of action is "emotivist" because it seems to assume that instincts are accompanied or maybe even triggered by emotions (e.g., fear triggers the conservation instinct). Actually most of them, such as Aron (1965) and Boudon (1994, 1999), do not use the word "emotivist," but their interpretation could nevertheless be called "emotivist." Both insist on "feelings" as the real source of actions in Pareto. Boudon tends to think that Pareto's sociology is causalist, weakly irrationalist and emotivist without recognizing clear differences between these categories. I claim, on the contrary, that these conceptual distinctions make sense and that they facilitate the evaluation of the empirical relevance of Pareto's sociology. This wording has been used in the context of the still contemporary, more or less rough opposition, between "emotivist" (Carnap, 1928, Ayer, 1936, Stevenson, 1937) and "cognitivist" (Toulmin, 1950) models. According to Carnap and Ayer, only scientific statements are based on reasons, while ethical and aesthetical statements are merely expressions of emotions. ${ }^{4}$ Toulmin argued, on the contrary, that ethics can be justified by reasons. It must be granted that Pareto does not stray too far from this kind of emotivist view. However, given that Pareto firmly distinguishes between instincts and emotions, it would be more

\footnotetext{
${ }^{4}$ See the general rediscovering of the role of emotions in cognition itself (e.g. Damasio, 1994).
} 
accurate to say that Pareto's theory is "instinctualist". ${ }^{5}$ According to Pareto, this narrow theory of action - or more precisely, of behavior - is valid for all animals and not only for humans $(\$ 155,156)$. Humans are different from other animals (or at least from most other animals) only to the extent that most of their actions are accompanied (and justified) by beliefs or alleged beliefs (§157). Again, one must agree that the Trattato includes such an emotivist - or rather instinctualist - theory $(\$ 850,868)$.

However, when we consider Pareto's general sociology, we find that it turns out to be mixed and to have both emotivist and cognitivist aspects. In the remaining sections of this paper I will focus on the cognitivist aspects of Pareto's sociology, which have been much underestimated in the existing scholarship. These new aspects consist of heuristic micro-models (or middle-range theories) closer to current psychological theories. Nevertheless, it is necessary to clearly first mark out the room allocated to instincts in Pareto's sociology of beliefs.

\section{AN EXPRESSIVIST AND COMMUNICATIVE SOCIOLOGICAL THEORY OF BELIEFS?}

\section{Expression, dissimulation and communication.}

According to one of the most widely shared views, Pareto's theory of action states that many human actions are not just "accompanied" by beliefs that do not play any role (as the eliminativist interpretation contends), but that these beliefs dissimulate the instinctual source and express an instinctual source different from the genuine source. Of course, this view is not incompatible with the eliminativist view: whereas many beliefs may be just epiphenomal by-products, many others may express/dissimulate instincts, and, as a result, play a role in the process of communication.

Actually, the theory of dissimulation is more often attributed to Pareto than the theory of expression. However these two (middle-range) theories are as complementary as the recto and the verso of a sheet of paper. Pareto provides many examples of this kind of beliefs, those that express certain instincts but dissimulate the genuine ones. Numerous examples are borrowed from political contexts. For instance, Pareto writes that politicians rarely try to persuade citizens to vote for them by invoking a love of power, for this would appear cynical. Rather, politicians claim that their goal is to serve the nation, and they attempt to make people believe that they seek the public good (§854). In certain cases, they may even succeed in persuading themselves that they are really motivated by such finer feelings (§854). Pareto does not deny that there is an "instinct" of solidarity in humans and in certain animals or other altruistic instincts such as compassion, and he suggests that these instincts might sometimes genuinely support the claim to believe in the value of solidarity and be the genuine source of action $(\$ 1138,1142,1144,1145,1146,1148,1150)$. Nonetheless, in the same passages, he

\footnotetext{
5 I do not want to use more common wordings such as "behaviorist" or "Darwinian" because these conceptions represent certain specific kinds of "instinctualist" theories among many possible others. On the relationship between Pareto's and Darwin's conceptions, see Lopreato and Crippen (1999). On the relationships with behaviorism, see Henderson (1935).
} 
says that invoking these instincts as the genuine source of one's own behavior is often both false and misleading, either deliberately (the alleged "beliefs" are merely apparent beliefs, both false and insincere) or involuntarily (the alleged beliefs, although objectively false _ because the genuine source is self-interest_are nevertheless sincere) (\$854). This account of beliefs is very close to La Rochefoucauld's, Nietzsche's and other classic authors. We might recall, for example, Marx's analysis of the self-interested motivations of the French delegates voting for the Declaration of the Rights of Man in Capital (1887, p. 518). Pareto even envisions cases in which the sexual instinct is the real source of certain actions, but is dissimulated by an idea that expresses a completely different instinct, e.g. a call for chastity (priests who continually discuss chastity in their sermons may actually be obsessed by sexuality) (\$852). Here Pareto is close to Freud. Globally speaking, one can conclude from these comparisons that Pareto's expressivist/dissimulationist theory of beliefs is not especially original. Nevertheless, this theory is different from eliminativist, anti-functionalist or purely instinctualist views since the expression of beliefs plays an effective role, actually a communicative role, either in indicating to other people the genuine source of actions or dissimulating the source and subsequently misleading people.

One can notice that Pareto is not very explicit on the idea that beliefs may express genuine instincts; rather Pareto emphasizes the idea of dissimulation. Commentators have claimed, therefore, that his sociology resembles the Machiavellan conception of political ideologies. They are right but, unlike these commentators, my central aim in this chapter is to extract from Pareto's sociology micromodels whose significance has been neglected or underestimated, precisely because they were less explicit in the Trattato.

Yet Pareto's theory is explicitly expressivist on another important aspect, since Pareto argues that humans need to express their feelings or instincts by external actions, if not explicitly by a kind of very specific action that one might call the discursive action of justification. Thus Pareto identifies a specific class of «residues »: "the need to express one's feelings by external actions" ( $\$ 888$ and $\S 1189-1112)$. This expressivist model focuses on the expressivity of actions much more than on the expressivity of discourse, but Pareto has less elaborated on this specific point than Malinowski. Thus, Malinowski (1922) describes at great length the importance of magical rituals (more than mere words) as a way of expressing deep feelings. .

Residues as instincts or primitive motivations. As mentioned previously, interpreters seem frequently to neglect that, according to Pareto, all beliefs are not necessarily false or insincere. True and sincere beliefs may exist. Pareto is ready to recognize that there may be genuine altruistic ( $\$ 1148$, $\left.\S 1152,5^{\circ}\right)$ or chaste behaviors $(\$ 1163,1165,1166,11787)$; this is clear given Pareto’s classification of what he prefers to call "residues" (what I have until now referred to as "instincts" for pedagogical reasons). We have also suggested that Pareto's conception of beliefs was probably influenced by 
Mill's System of Logic. Commentators on Pareto's sociological theory have not often noticed, at least to my knowledge, that Mill also uses the word "residue" in his account of scientific method. Pareto very probably borrows this term from Mill, as he does the word "derivation" (to be discussed shortly), although Pareto intends the words to have different meanings from Mill's usage. ${ }^{6}$ Let us now turn our attention to the general idea that "residue" is a methodological term and to the fact that Pareto prefers to speak of "residue" rather than of "instincts" for methodological reasons.

Pareto often uses the term "residue" in the framework of the previous micro-theory; in particular, he uses the term when he claims that beliefs are the mere by-products of instincts that have the capacity to dissimulate the real source of actions. In fact, when these beliefs (or rather alleged beliefs) are analyzed and reduced, what remains are the "residues" of analysis $(\$ 851,862)$. The real source of actions, then, is merely instincts. But because these instincts have not been discovered directly, but only via the analysis of beliefs expressed in discursive reasoning, Pareto does not contend that he has given a correct account of them that might be comparable to what a neurologist or a psychologist using other methods could produce $(\$ 851,852)$. He uses only what is sufficient to take beliefs or alleged beliefs into account within a sociological framework. This may help explain why Pareto does not try to reduce the numerous residues-instincts (six classes divided in many sub-classes) to a smaller number, as does Freud for drives (only two: sexual drive vs instinct of preservation; or later: Eros $v s$ Thanatos).

Pareto never makes any reference to Mills' Method of Residue, one of the four scientific Methods with the Method of Agreement, the Method of Difference and the Method of Concomitant Variations (Mill, 1963, Book III, Chapter VIII). However the process I have described as Pareto's method is very close to the Method of Residue, which Mill illustrates by examples drawn from Astronomy, Physics or Chemistry if not from Psychology or Sociology (Mill, 1963, Book III, Chapter VIII, §5). Because the term "residue" is a methodological term, Pareto can use it in other contexts, yet it takes on different meanings in those new contexts. It is a mistake to state that residues always deal with instincts; even more important, we cannot say that residues always deal with emotions. Some classical authors, such as Parsons (1936), as well as a few historians of sociological theory, such as Turner, Beeghley and Powers (1981, pp. 386-90), have clearly observed as much; I will attempt to confirm their insights shortly.

These residues are, if not the ultimate source of action or the ultimate principles of action, at least close to them. Pareto could have used this very phrasing ("ultimate principles"), and then followed Mill's usage. In fact, Mill makes a distinction between derivative laws and primitive laws, which he sometimes calls ultimate laws or ultimate principles (Mill, 1963, Book III, Ch. XIV, §1; Ch.

\footnotetext{
${ }^{6}$ Because of a lack of space, I will not examine in further detail here (see Bouvier, 1995) the differences in usage between Mill and Pareto.
} 
$\mathrm{XV}, \S 3$, etc.). He specifies that the primitive laws or principles can be discovered by backward reasoning from derivative laws. Mill's notion of law is very close to the notion of cause. Indeed, if we ignore the exact wording (in terms of "laws"), Pareto resembles Mill even more closely. Pareto also seems to have isolated "instincts" through a process of backward reasoning. Pareto most likely began his research by considering certain effects or expressions (“derivative principles") of instincts and then attempted to find their cause or source ("primitive - or ultimate - principles") (§886). At the same time, Pareto seems to have thought that genuine ultimate principles - "instincts" - probably lie beyond residual instincts - because, after all, he arrived at a discussion of residual instincts only indirectly.

Derivations as derivative motivations in Mill-Pareto's model. Pareto calls the justifications of beliefs "derivations" (or sometimes "derivative", §868, 879-880, 1397). But Pareto often uses the word "residues" and the word "derivation" in so different meanings, depending on contexts, that what is called "residues" from a certain aspect can be viewed as "derivation" from another (e.g., §877, 882). Thus, I would like to claim that the use of the term "derivation" to designate beliefs or alleged beliefs not only is useless for us at the present stage in this account of Pareto's theory of actions and beliefs but even misleading. One could surely say here, following Mill's usage, that some instincts are less primitive than others, and consequently are "derivative," - for example, self-interest preservation of individual integrity might be more primitive than solidarity $(\S 1138-9, \S 1152)$ - although Pareto does not use the term "derivation" and "derivative" in this sense when he refers to residues as instincts (as we will soon see, he uses these same words in other contexts). When Mill speaks of the properties of objects, he makes a distinction between primitive (or, more exactly, ultimate) properties and derivative properties, and takes the example of chemical bodies (Mill, 1963, Book I, Chapter 7, §6; Book III, Chap. 20, §2). One of Mill's main concerns in this context is to account for what is now called the emergence (and sometimes the "supervenience") of properties upon others. Mill sometimes speaks of the "generation" or the "production" of these proprieties in place of "derivation," as if these words were interchangeable. But again, the classification of "residues" (namely instinctual residues) does not make any clear reference to this idea. Although Pareto seems to be sometimes close to such a viewpoint (\$876), he never speaks explicitly of elementary instincts, nor does he mention “compounds" of elementary instincts (§ 888. Bouvier, 1992, n. 19 p. 355-6).

One could also argue, extending some of Pareto's seminal ideas within Mill's conceptual framework, that certain instinctual residues (or motivational principles) are more primitive than others but that derivative (motivational principles) are invoked more often because they are more readily accepted by human society (\$854). Without any reference to Pareto, Elster (1999) has recently envisaged how feelings can transform themselves into other feelings. We could say, then, that some feelings are primitive and others are derivative, at least functionally. 
To conclude our examination of this account, let us take up the notion of residue as an indication of one methodological way by which the real source of actions can be discovered, and let us lay aside the notion of derivation, as it is misleading in this framework - except if we use it in the manner Mill used it. In this case, some instincts (discovered through the Method of Residues) are primitive and others are derivative. One might even add that the former kind of instincts might be said to be more residual than the latter, since backward reasoning should lead us from the latter to the former.

Finally, we have to notice that, unlike the eliminativist account in particular, Pareto's expressivist/dissimulationist account of beliefs in relation to instincts attaches a communicative value to beliefs expressed in discourse.

\section{A SOCIOLOGICAL THEORY OF BELIEFS AS INVOLVING LOGICAL DEDUCTIONS}

In numerous passages, Pareto does not focus on the emotive (or instinctual) dimension of beliefs, but on the contrary, on their cognitive - more precisely, their logical - dimension (1405-1418, 1543-1686). This viewpoint converges with a conception of residues as either moral principles or metaphysical/physical principles.

A/ Residues as primitive moral principles and derivations as derivative moral principles in Mill-Pareto's model.

According to a more refined view than the "instinctualist" view of Pareto's theory of beliefs and actions (which we examined in the previous sections), Pareto's viewpoint deals more with an account of moral standards or common moral principles, which vary depending on groups and societies, than with a search for instinctual (and universal) principles. According to this model just outlined in the Trattato, what motivates action are not mere instincts but rather moral principles, which require consciousness although instincts are unconscious. Nevertheless, Pareto remains ambiguous on this point. In fact, Pareto often speaks of "moral feelings," which could refer either to instinctual emotions corresponding to moral virtues like pity or compassion, or to moral principles themselves. He also speaks of "moral feelings" and "moral principles" as if the terms were interchangeable (\$1113-1206). Of course, one might say that altruism is based either on the instinct of solidarity, or that it is based on an explicit moral imperative requiring one to exhibit solidarity. As mentioned earlier, Parsons and Powers have rightly focused on the moral use of the word "residue," but Parsons did it so much that he has tended to understand residues as nothing more than moral principles - in complete opposition to the most common commentaries on the subject.

The reducibility of moral principles to moral feelings has been a vexing philosophical issue since at least Kant's day, and the discussion is still lively. According to one common conception, which resembles Hume's thought closely, morality follows spontaneous tendencies. According to a 
second line of reasoning, closer to Kant's, true morality is duty - in which action does not follow tendencies but has to work against them. In this view, morality begins only when one exhibits altruistic behavior to people for whom one does not feel any sympathy. It is clear that Pareto does not believe in Kant's account of morality. Furthermore, Pareto maintains that moral principles express only spontaneous tendencies; consequently, moral principles are reducible to tendencies. Nevertheless, he turns out to be also very much interested in analyzing the actual content of moral theories.

In this context, Pareto again uses the word « residue », as well as the word « derivation », but he uses them in two different senses. Let us now focus on one meaning only. According to Mill's usage (yet Mill does not use these words for moral examples in the System of Logic), if the residue is a primitive moral principle, for example, "Stand in solidarity with others," the derivation would be constituted of the logical consequences of this general principle, allowing it to apply to particular situations (e.g., "Send money to Haitians so they may survive after the earthquake"). Pareto, however, is not concerned with the particular logical consequences ("derivations" in Mill's sense) of such a general principle. He is concerned with the account for the varieties of moral systems in the human world _ there is Kant's ethics, but also Christian Ethics, Muslim Ethics, Utilitarian Ethics (such as Mill's Ethics), Stoicism, Epicureanism and a multiplicity of tribal Ethics _ whose goal is to justify this kind of principle itself, so that this moral principle ("Stand in solidarity with others") turns out to be $a$ logical consequence of more primitive principles. It is these deductions that Pareto calls "derivations." The use of the term "derivation" here is an example of Pareto's indeterminate use of concepts. In fact, the statement "Stand in solidarity with others" might be viewed, if we consider it in light of certain lexical uses of the words in the Trattato, merely the expression of an (instinctual) residue ( $\$ 970, \S$ 1113-1206). According to other lexical uses in the Trattato, however, the same statement would be viewed as a derivation understood as a logical consequence of alleged more primitive principles (either theological, like in Christianism, or political, like in Marxism, or metaphysical, magical, etc...)(§ 863, $\$ 1414, \S 1416$, etc.).

Even if Pareto does not refer to Mill as much as he could have, it is nonetheless remarkable that his thought bears a striking resemblance to other aspects of Mill's thought. It is even more surprising that Pareto fails to refer to a famous example in the System of Logic, an example which would have served to illustrate his argument. In that passage, Mill (1963, Book II, Chapter III, §3) refers to Lord Mansfield's famous advice to a juror who did not know the morals and laws of the country where he would be staying: "Try to judge according to your deepest intuitions but above all get out of any justification of your judgment." In other words, the juror's judgment would probably be fair, but his justifications would surely be wrong. Pareto, for his part, writes: "in non- scientific reasoning, what usually happens is that abandoned premises are replaced by new ones - one residue gives way to other residues" ( $\left(1416,2^{\circ}\right)$. Pareto refers to various examples, especially moral examples. For example, Theist premises may take the place of Catholic premises, and if these 
premises are abandoned, they in turn may be replaced by Marxist premises. Nonetheless, the logical consequences will roughly be the same in every culture (e.g. lying, thievery, and murder are prohibited in every culture, except in particular circumstances which are always more or less the same, such as self-defence). We might take note of the fact that Mill's and Pareto's skepticism about the general justifications of moral judgments is in line here with Hume, and it should also remind us of Aristotle's casuistic ethics (as opposed to Kant's ethics). As such, Pareto's account of moral and juridical reasoning is not especially original.

Within the framework of this sociological theory of moral beliefs as logical deductions (or "derivations"), Pareto makes a further distinction between simple deductions or derivations, and complex deductions or derivations, meaning that both may have exactly the same normative conclusions. He takes the example of Marxism, of which more or less sophisticated versions exist. It goes without saying that The Capital is much more complex than The Communist Party Manifesto, but the normative message of both texts is nevertheless the same (§1416). Pareto writes that more sophisticated versions serve only to lend intellectual authority to the author's conclusions. This means that such works are not useless, since they are more easily accepted by cultured people. Pareto does not elaborate further on this point, but one can infer that the instinct to rationalize is probably stronger in certain people. Therefore, such people need more complicated justifications (derivations) to be satisfied. To restate what we have said previously, Pareto's account of collective moral beliefs is quite close to Malinowski's account of cultural variety. Malinowski (1926) tended to think that common sense in the evaluation of behaviors is universally widespread, more so than it might seem at first glance. Nonetheless, the beliefs that justify behaviors vary according to cultural and historical context.

Within the framework of this same micro-theory that seems to emerge here, Pareto notices that one can observe both a call for the defense of the integrity of one's own person, and a call for compassion towards other people. According to Pareto, this suggests that residues as instincts act in opposition to one another, and residues as moral principles do so as well (§888). Jon Elster (1999) has emphasized this aspect in his recent work. Elster cites traditional proverbs to show how justifications for behaviors are so incredibly varied that for every proverb recommending a certain course of action, another proverb that advises exactly the opposite behavior can be found.

Pareto also adds that most principles that seem to be quite radical in principle (for example, "It is forbidden to kill anyone"), may include exceptions under certain circumstances (for example, one might kill another person in order to save one's life, or in defense of one’s country) (§1558). These exceptions, however, will be explicitly specified only when one is confronted with such circumstances (§1558). Of course, it is always easy to be insincere and, like the Jesuits, to add ad hoc exceptions that promote one's own self-interest when moral principles obstruct the accomplishment of one's goals. Furthermore, moral principles may seem significantly more different than they actually are if one 
remains attached to merely ideological principles instead of to effective principles. Again, Pareto's statements are close to Malinowski's (1926).

B/ Residues as metaphysical (or physical) principles and derivations as metaphysical (or physical) or normative logical consequences. A more general sociological theory of beliefs _ normative or not_as logical deductions.

Depending on the context, Pareto focuses on very different aspects of beliefs, which helps explain why numerous outlines of micro-models or middle-range theories can be found in the Trattato. Thus, according to the previous account, as partial as the other ones, of course, primitive principles of which logical conclusions can be derived are always moral principles, possibly expressing moral instincts.

But now the most important point, compared to what has been stated above, is that the principles of which moral conclusions such as the appeal to solidarity or the interdiction of killing are drawn are not necessary themselves moral principles. This proves, once again, that residues are not reducible to moral principles or moral feelings - but Pareto calls them "residues" as well. He is speaking here of a "metaphysical residue" (§1414), for example, regarding the existence of a god as a principle upon which the interdiction of murder is based.

Compared to other anthropological theories, Pareto does not stray far from naturalist views. However, Pareto does not give any explanation of the origin of ideas such as God or other religious ideas. On the contrary, Pascal Boyer (1994), a contemporary anthropologist who does not focus on the explanation of moral justifications, but rather on religious ideas, sets forth an original idea on this subject. Boyer does not argue that all religious ideas are based on the same universal primitive ideas which might be in line with Pareto's general views on collective beliefs, but seems hard to demonstrate according to most anthropologists, given the great variations in religious beliefs. Instead, Boyer argues, on the contrary, that all religious beliefs are based on the same cognitive mechanism tending to violate these universal basic ideas or these primitive "categorizations", such as the belief that a stone cannot fly and does not need to eat because a stone is a mineral object and that such objects cannot fly and do not need to eat. This issue remains open for debate, although it is not certain that Boyer's account is as original as it seems at first glance. Nonetheless, Boyer provides us at least with a more precise and developed discussion of the already common idea that religious ideas are concerned with "supernature" (supernatural entities), that is: they deal with a kind of causality different from natural causality (Evans-Pritchard, 1937, 1965).

Although Pareto does not say anything as explicit on the supernatural, he does take note of the fact that when people refer to God or other supernatural entities such as Poseidon, they do not renounce their more rational beliefs according to scientific criteria. Thus, sailors continue to repair 
their ships even if they use protective magic also. All empirical anthropologists, from Malinowski (1922) to Evans-Pritchard (1937), have written about the same phenomenon. Evans-Pritchard wrote, with language very similar to Lévy-Bruhl's (1910), that many people believe that there are two kinds of causality, natural and supernatural, and that they do not conflict. The latter merely complements the former. If Pareto would have elaborated a little more on that point, he would probably have said that supernatural explanations are complex and various derivations, while natural explanations are simple and more or less universal explanations. Evans-Pritchard (1965) mentioned that Pareto's and LévyBruhl's intuitions were very similar but that Pareto thought that supernatural or magic explanations can be found even in occidental and allegedly rationalist countries.

4. A SOCIOLOGICAL THEORY OF BELIEFS AS CONSEQUENCES OF INVALID YET CONVINCING LOGICAL DEDUCTIONS.

The previous section turned our attention to the theory of collective beliefs outlined in the Trattato, and focused on comparisons between various deductive justifications. In this model, the logical validity of these deductions is not under discussion. Pareto compares the different content of logical premises that nonetheless leads to the same conclusions, or he compares premises whose core content is identical, but which differ greatly in their degree of complexity, and yet lead to the same conclusions. The greatest part of the chapter X of the Trattato (\$1543-1686), however, is devoted to the examination of the numerous invalid logical deductions that one may encounter in the examination of justifications of collective beliefs. This new investigation can give birth to a still slightly different (middle-range) theory of beliefs. I claim that this theory is the most original part of Pareto's general theory of collective beliefs. And I argue that this theory is still stronger if one introduces Mill's psychological views, which are more refined. Those views are now being rediscovered by contemporary experimental cognitive psychologists, but still neglected by sociologists. I will set forth these ideas in the next two sections.

Pareto devotes hundreds of pages to what he calls "verbal derivations" (or "verbal proofs"), which are justifications of beliefs comprising logically invalid deductions (§ 1543-1686). To be more precise, not only does Pareto speak of justifications that are logically invalid, but he also speaks of justifications that are logically valid but are based on empirically false premises. Of this latter kind is the belief that Poseidon exists; that he plays a (supernatural) role in the genesis of storms; that he is sensitive to human prayers and rituals; and, consequently, that it is wise to pray to Poseidon and make relevant rituals before departing on a sea-going voyage. Mill also makes this distinction in his System of Logic, in the book entitled "On Fallacies" (Book V). Malinowski and Evans Pritchard - and even Levy-Bruhl - cite examples very similar to Pareto's. But Pareto is the only one of the four who focuses on logically invalid justifications, and is also the only one to be in line with Mill (§1410-2), following Hume. I argue that Pareto's most original idea is that most beliefs are irrational in a very 
specific sense, that of logical invalidity. This account of beliefs differs even from Lévy-Bruhl's account of primitive collective ideas as "pre-logic" since "pre-logic" in Lévy-Bruhl's thought does not mean "not logic". It merely means that the premises of (valid) deductions include some kind of reference to supernatural entities and properties

Many contemporary psychologists since Tversky, Kahneman and Slovic (1980), and Nisbett and Ross (1980), have focused attention on the very numerous logical mistakes that everyone - even logicians or statisticians - commits in everyday life, sometimes with serious consequences. For example, a physician might incorrectly interpret medical tests and conclude that a patient is suffering from AIDS or another very serious illness, when in fact that is not the case. Further investigations have shown that these common mistakes are far less frequent than first experimentalists believed. Many of them appear only within experimental contexts, so that many of the alleged logical mistakes can be taken as experimental biases (Gigerenzer, 2000). Nonetheless, many mistakes remain. In any case, all treatises of logic from Aristotle to John Stuart Mill include an examination of logical mistakes, yet further proof that they do exist. Indeed, Gigerenzer explained the existence of logical fallacies rationally by showing that the most frequent logical fallacies are merely by-products of heuristics that were the most valuable in the dangerous environments where our ancestors lived. (They provided faster results than more careful reasoning). Nonetheless it does not change the fact that the mind produces such mistakes.

Pareto does not use the "principle of charity" in Davidson's sense (Davidson, 1982), which enjoins the social scientist to suppose, a priori, that even if a belief or an action seems strange, the believer or the actor had good reasons to believe or act as he did. In consequence, often Pareto commits biases comparable to laboratory biases encountered by psychologists. On many occasions, for example, when Pareto investigates the reasoning of classical philosophers like Plato, Rousseau, Kant, and Hegel, one can easily claim that the supposed invalid reasoning diagnosed by Pareto is actually valid in almost every case if one interprets the phrasing correctly ( $\$ 1507,1514-22,1556,1682)$. Nevertheless, certain kinds of reasoning still involve logical mistakes, at least if one uses the principle of charity only as a heuristic rule of interpretation and not as a rationalist dogma. In fact, Pareto is fully aware that it is often easy to transform defective reasoning into correct reasoning by introducing new premises, stating that they were implicit (\$1405-9), or by restricting the scope of another premise (§1558), or by changing the meaning of a term (\$1556-1613), and so on. Of course, Pareto is right here in arguing that these devices may be fully insincere, and that the one who made the mistake simply did not want to admit that he was wrong. But we must consider each case individually. In any case, Pareto's attempt to investigate the role of the most frequent fallacies in societies is both an original and a relevant research program $(\$ 1411)$. 
Among the numerous historical examples of fallacies that he analyses, Pareto investigates at length the fallacies of composition and division (also termed "fallacy of distribution" or "fallacy of apportionment”) (\$1495-6). And yet Pareto is often more inclined to give brief sketches of these many examples rather than to analyze some of them carefully or show their historical significance. Albert Hirschman (1977), on the contrary, has brilliantly shown how frequent these fallacies have been used both to justify and refute capitalism. I have personally tried to show that one particular kind of fallacy (that went unnoticed by Pareto), a fallacy, that since the Stoics, has been called "the lazy argument," appears in very different contexts, from common interpretations of Calvinism to common interpretations of Marxism (Bouvier, 1999b).

I argue that this specific micro-model or "middle-range theory" in Pareto's sociology of beliefs has been seldom recognized because it has often been confused with the dissimulationist theory of beliefs, which is yet another middle-range theory (see above). A dissimulationist theory can still be discerned here, in a sense, but what remains hidden are not feelings or instincts but rather metaphysical, physical or normative principles. Furthermore, what covers over these principles are not other feelings or instincts but logico-linguistic tricks. This is a significant difference because these kinds of dissimulations are independent. In particular, certain justifications (e.g. invoking solidarity), may dissimulate the genuine motivations (e.g. self-interest), without using logically invalid reasoning and linguistic tricks ("Send money to Haitians so they may survive after the earthquake" can be justified - and logically deduced - from the general principle "Stand in solidarity with others", although this principle may dissimulate the genuine principle: "Be recognized as generous if you want to become a political leader"). Other justifications dissimulate genuine motivations by using logicolinguistic fallacies (e.g. using the word "solidarity" in different senses, $\S 1557$, or the fallacy of division, § 1497); they are twice misleading.

\section{A RETURN tO tHE CAUSALIST AND RATIONALIST THEORY OF BELIEFS, AND TO ITS}

\section{COMMUNICATIVE DIMENSION}

These two last theories of beliefs open the way for further interrogations into the nature of Pareto's general viewpoint. Indeed, Pareto gives us an explanation of the logical mistake that is in accordance with the first theory we have explained, that is, the instinctualist or emotivist theory. References to contemporary debates can also help us here. Nisbett and Ross (1980) wonder about the origins of logical mistakes, but take for granted that such mistakes exist and that they are not created only by methodological biases. For pedagogical reasons, they argue that in this respect there are two kinds of theories, "hot" and "cold." Advocates of hot theories contend that logical mistakes are caused by emotions: it is when people are stressed or tired, for example, that they commit logical mistakes. Proponents of cold theories argue that logical mistakes are caused by cognitive biases, namely strong cognitive tendencies, such as heuristics permitting people to think by following ways that are 
particularly rapid and generally right but that can be misleading in certain specific cases. Pareto explicitly supports a hot theory on these matters. When he sets forth his view on this issue, he refers to Mill, but strangely he attributes a view to Mill that is obviously not Mill's own (§1410;1412), showing that he read Mill very quickly (Bouvier, 1995, 1997). It is a pity, because Mill's view is much more elaborated than Pareto's and may perhaps be even more in accordance with the great varieties of models that Pareto, in fact, provides. In reality, Mill's psychological account of logical mistakes is a mixed theory. Mill argues that, on the one hand, emotional causes and, on the other hand, intellectual or cognitive causes, have to be connected: emotions may play a role, but emotions cannot produce logical mistakes if a kind of autonomous cognitive weakness does not exist already (Mill, 1963, Book $\mathrm{V}$, Chapter 1, § 3). Psychology, then, should investigate both kinds of causes.

A consequence of this kind of analysis, which I will take as well-founded without having room to prove it (Bouvier, 1992, 1995), is that justifications of beliefs, whether true or false - false for logical or empirical reasons - must have an effective role in the perseveration or transformation of collective beliefs. In such a way, the communicative theory of beliefs (see above) is enriched by a more complete causalist theory, in which reasons, even false reasons, play a role.

\section{6/ THE LIMITS OF PARETO’S ACCOUNT OF COLLECTIVE BELIEFS}

To conclude, I will point out only two limitations to Pareto's theory - or theories rather, since Pareto's account of collective belief is not systematic and he provides only micro-models or "middlerange theories" in Robert Merton's sense.

First, although Pareto takes argumentation into account, he investigates fallacies almost exclusively. What is worse, when he encounters argumentative procedures such as analogies, he views them only as tricks, even though they could play a positive pedagogical role in the explanation of new ideas (without speaking of their heuristic role, which historians of science such as Mary Hesse (1966) have proved). The same could be said of other procedures such as what Bakhtin (1984) calls polyphony, which Pareto notices in interpretations of the Song of Songs in the Bible ("St Jerome (...) assumes without trace of proof that the author is not speaking of himself when he recommends conviviality at table",§1629). Perelman's Treatise on argumentation (Perelman and Olbrecht-Tyteca, 1958) enriched by more contemporary investigations, would be a better guidebook than Pareto's Trattato for the analysis of argumentation procedures because it is less repetitive and more systematic. Furthermore, better examples of applications to historically significant ideas can be found elsewhere than in Pareto's writings. Hirschman (1977) has shown, in a famous book I already mentioned, that logically valid arguments played a role in the transformation of prominent collective feelings or instincts in the $17^{\text {th }}$ and $18^{\text {th }}$ centuries, leading young men to seek their self-interest rather than glory and honor. 
Second, and more important, Pareto provides a very narrow analysis of collective beliefs as collective. Collective beliefs in the Trattato are merely widespread beliefs - that is, beliefs that many individuals have objectively in common. But Pareto does not elucidate the process by which certain beliefs are viewed by folks as constitutive of their community. And he does not investigate either the various processes by which people may feel socially forced to publicly accept certain ideas they do not personally accept. Both Tocqueville and Durkheim have given us much deeper understanding of collective beliefs from these viewpoints. An examination of their ideas is outside the scope of the present paper. Returning to works introduced at the beginning of this paper, I want to put forward the idea that both Margaret Gilbert and Jon Elster have provided illuminating analyses of collective beliefs based either on Durkheim (and the notion of "joint commitment") (Gilbert, 1989) or on Tocqueville (and the notion of "pluralistic ignorance") (Elster, 2007).

To conclude, I claim that Pareto's sociology of collective beliefs contains numerous outlines of heuristic micro-models or "middle-range" theories of collective beliefs whose heuristic significance has been underestimated. Generally speaking, scholars have insisted on irrationalist, instinctualist and emotivist dimensions of Pareto's account. A re-reading of the Trattato in line with Mill's System of Logic enhances its cognitive dimensions, quite underestimated. However one is far from an overarching theory of collective beliefs, not only because Pareto's views still remain too narrow, but also because his views are not systematical: the various micro-models are not set up in a systematic theory. Above all, in order to speak of middle-range theories in Merton's proper sense, this examination should be complemented by case studies. But this task oversteps the scope of this paper.

\section{References}

Aron, R., 1965, Main Currents in Sociological Thought,2, New York, Doubleday

Ayer A. J., 1936, Language, Truth and Logic

Bakhtin, M. M., 1984, Problems of Dostoevsky's Poetics. Minneapolis: University of Minnesota Press

Boudon, R., 1981 [1979], The logic of social action. An introduction to sociological analysis, Routledge \& Kegan Paul in London, Boston .

Boudon R., 1994 [1990], The art of self-persuasion, London, Polity Press.

Boudon, R. 1999, “ L'actualité de la distinction parétienne entre "actions logiques" et "actions non logiques” in Bouvier (1999), pp. 35-70.

Bouvier, A., 1992, "Modèles parétiens en théorie des idéologies / sociologie des représentations" in L'Année sociologique, Vol. 42, p. 345-368.

Bouvier, A., 1993, "Une anthropologie sociologique des topoï : la théorie des dérivations de Pareto" in Ch. Plantin (dir.), Lieux communs, topoï, stéréotypes, clichés, Ed. Kimé, Chap. 18, p. 182-192

Bouvier, A., 1995, « Les paralogismes d'un point de vue sociologique », in Hermès, n ${ }^{\circ}$, pp.45-55. 
Bouvier, A., 1997, "Un paradigme caché en sociologie de la connaissance scientifique : le paradigme Mill-Pareto", Revue européenne de sciences sociales. Cahiers Vilfredo Pareto, t. XXXV, n¹08, p. 1530.

Bouvier, A. (dir.), 1999a, Pareto aujourd'hui, Paris, Presses Universitaires de France.

Bouvier, A., 1999b, « Naturalisme et actionnisme chez Pareto. Pertinence des problèmes parétiens en sociologie cognitive », in A. Bouvier (dir.), Pareto aujourd'hui, Paris, P.U.F., 1999, pp. 273-292.

Bouvier, A., 1999c, "La théorie de l'équilibre général chez Pareto : une théorie paralléliste. Versant causal et versant intentionnel de l'équilibre social", Revue européenne des sciences sociales. Cahiers Vilfredo Pareto, t. XXXVII, n 116 , p. 245-258.

Bouvier, A., 2000, Le dépassement du Rational Choice Model en sociologie" in Corrado Malandrino e Roberto Marchionatti, Economia, Sociologia e Politica nell'opera di Vilfredo Pareto, Leo S. Olschki editore, Firenze, p. 297-312.

Bouvier, A, 2005, «Le programme argumentativiste en sociologie et en anthropologie cognitives », in Nicole Ramognino et Pierre Vergès, Sciences sociales et sciences cognitives, Aix-en-Provence, Presses Universitaires de Provence, pp. 105-142.

Boyer, P., 1994, The Naturalness of Religious Ideas. A Cognitive Theory of Religion, Berkeley, University of California Press.

Burnham, J., 1943, The Machiavellians. Defenders of Freedom, New York, The John Day Company, Inc.

Busino, G., 1999, "Lire Pareto aujourd'hui” in Bouvier (dir.), 1999, pp. 23-33.

Carnap, R., 1928(1967), The Logical Construction of the World, Berkeley and Los Angeles,

University of California Press.

Carroll J., 1973, Pareto's irrationalism, Sociology, Vol. 7, No. 3, 327-340 (1973), reprinted in Femia, J., 2009.

Churchland, P. M., 1984. Matter and Consciousness. Cambrigdge, MA: MIT Press.

Damasio, A.R, 1994, Descartes' Error: Emotion, Reason, and the Human Brain, Putnam Publishing.

Davidson, D., 1982, ‘Two Paradoxes of Irrationality', in R. Wollheim and J. Hopkins (eds.)

Philosophical Essays on Freud, Cambridge: Cambridge University Press, 289-305.

Elster, J., 1985, Making sense of Marx, Cambridge, Cambridge University Press.

Elster, J., 1993, Political Psychology, Cambridge, Cambridge University Press.

Elster J., 1999, Alchemies of the Mind. Rationality and the Emotions, Cambridge, Cambridge University Press.

Elster, J., 2007, Explaining Social Behavior: More Nuts and Bolts for the Social Sciences, Cambridge, Cambridge University Press.

Evans-Pritchard, E., 1965, Theories of Primitive Religion, Oxford, Oxford University Press 
Evans-Prichard, E., 1937, Witchcraft, Oracles and Magic Among the Azande, Oxford, Oxford University Press.

Femia, J., 2006, Pareto and Political Theory, Routledge.

Femia, J. (ed.), 2009, Vilfredo Pareto, Ashgate

Fiorot, D., 1969, Il realismo politico di Vilfredo Pareto, Milano, Edizioni di Comunità

Gigerenzer, G., 2000, Adaptive thinking: Rationality in the real world. Oxford, Oxford University Press.

Gilbert Margaret, 1989, On social facts. Princeton, Princeton University Press.

Gilbert, M., 1994, "Durkheim and Social Facts" in W. Pickering and H. Martins, Debating Durkheim, London: Routledge.

Habermas, Jürgen, 1984-7, The Theory of Communicative Action, Cambridge: Polity.

Hamblin, C.L., 1970, Fallacies, London, Methuen \& Co Ltd.

Hedström, P. and Swedberg, R. (eds), 1998, Social Mechanisms. An Analytical Approach to Social Theory, Cambridge, C.U.P.

Hedström, P. and Bearman, P. (eds), 2009, The Oxford Handbook of Analytical Sociology, Oxford, Oxford University Press.

Henderson, L.J., 1935, Pareto's General Sociology: A Physiologist's Interpretation, Cambridge, Harvard University Press.

Hesse, M., 1966, Models and Analogies in Science, Notre-Dame, Univ. of Notre-Dame Press.

Hirschman, A., 1977, The Passions and the Interests: Political arguments for capitalism before its triumph, Princeton, NJ: Princeton University Press

Hirschman, A., 1991, The Rhetoric of Reaction: Perversity, Futility, Jeopardy. Cambridge, MA: The Belknap Press of Harvard University Press

Homans, G.-C., 1941, "Anxiety and Ritual: The Theories of Malinowski and Radclidffe-Brown Sentiments", in George C. Homans, Sentiments and Activities: Essays in Social Science, New York, Free Press of Glencoe, 1962, chap. 13, pp. 192-201.

Homans, G.-C., 1950, The Human Group, New York, Harcourt, Brace and World.

Lévy-Bruhl, L., 1910, Les fonctions mentales dans les sociétés inférieures, Paris, Alcan.

Lopreato, J. and T. Crippen, 1999, Crisis in Sociology. The Need for Darwin, New Brunswick, Transaction Publishers.

Malinowski, B., 1926, Crime and Custom in Savage Society, London, Routledge.

Malinowski, B., 1922, Argonauts of the Western Pacific, E.P. Dutton \& Co. Inc.:New York.

Marshall, A.J.M., 2007, Vilfredo Pareto's Sociology. A Framework for Political Psychology, Ashgate, Aldershot. 
Marx, K., 1887 (1867), Capital. A Critique of Political Economy, Vol. 1, Progress Publishers, Moscow, USSR, http://www.marxists.org/archive/marx/works/1867-c1/index.htm.

Merton, R., 1957, Social Theory and Social Structure, Glencoe, Ill., Free Press.

Mill, J. St., 1963-1991 (1843) A System of Logic, Ratiocinative and Inductive, in The Collected Works of Stuart Mill, T. VII, Toronto, Univ. Of Toronto Press.

Nisbett, Richard and Ross, Lee, 1980, Human Inference: strategies and shortcomings of social judgment, Englewood Cliffs, N.J., Prentice-Hall.

Pareto, V., Mind and Society, 1935, Harcourt, Brace [transl. of Pareto, 1916, Trattato di Sociologia Generale]

Parsons, T, 1936, "Pareto's Central Analytical Scheme" in Talcott Parsons, The Early Essays, Chicago, The University of Chicago Press, 1991, pp. 133-150.

Parsons, T., 1937, The Structure of Social Action, Dubuque, McGraw Hill

Parsons, T., 1951, The Social System, London, Routledge and Kegan Paul

Perelman Chaïm and Lucie Olbrecht-Tyteca, 1969 [1958], The New Rhetoric. A Treatise on Argumentation, Notre Dame (Ind.): University of Notre Dame Press.

Pinker, St., 1997, How the Mind Works, New York, W. W. Norton \& Company

Powers, Ch., 1987, Vilfredo Pareto, Beverly Hills, Sage Publications.

Skorupski, J., 1998, "Mill on language and logic" in Skorupski, J. (ed.), 1998, The Cambridge Companion to Mill, Cambridge, Cambridge University Press, pp. 35-56.

Stevenson, C. L., 1937, "The Emotive Meaning of Ethical Terms", in Stevenson, 1963, C. L.. Facts and Values, Yale University Press.

Toulmin, Stephen, 1950. An Examination of the Place of Reason in Ethics. Cambridge: Cambridge University Press.

Toulmin Stephen, 1958, The Uses of Argument, Cambridge : Cambridge University Press.

Turner, J.-H., Beeghley, L. and Powers, Ch., 1981 (eds), The Emergence of Sociological Theory, Wadsworth Publishing Company, Belmont.

Tversky A., Kahneman D. and Slovic P., 1980, Judgment under Uncertainty. Heuristics and Biases, New York, Cambridge University Press

Valade, B., 1990, Pareto, la naissance d'une autre sociologie, Paris, Presses Universitaires de France

Winch, P. 1958, The Idea of a Social Science and its Relation to Philosophy, London, Routledge.

Wittgenstein, L., 2001 (1953), Philosophical Investigations, Blackwell Publishing 